\title{
Hypertension in Thyroid Disorders
}

\author{
Eszter Berta ${ }^{1,2}$, Inez Lengyel ${ }^{1}$, Sándor Halmi ${ }^{1}$, Miklós Zrínyi ${ }^{3}$, Annamária Erdei ${ }^{1}$, \\ Mariann Harangi ${ }^{4}$, Dénes Páll ${ }^{3}$, Endre V. Nagy ${ }^{1}$ and Miklós Bodor ${ }^{1,2 *}$
}

\begin{abstract}
${ }^{1}$ Department of Endocrinology, Faculty of Medicine, University of Debrecen, Debrecen, Hungary, ${ }^{2}$ Department of Clinical Pharmacology, University of Debrecen, Debrecen, Hungary, ${ }^{3}$ Coordination Center for Drug Development, University of Debrecen, Debrecen, Hungary, ${ }^{4}$ Department of Metabolism, Faculty of Medicine, University of Debrecen, Debrecen, Hungary
\end{abstract}

\section{OPEN ACCESS}

Edited by:

Teresa Seccia,

University of Padova, Italy

Reviewed by:

Caterina Mian

University of Padova, Italy

Alain Couvineau,

Institut National de la Santé et de la

Recherche Médicale

(INSERM), France

${ }^{*}$ Correspondence:

Miklós Bodor

bodor.miklos@med.unideb.hu

Specialty section

This article was submitted to

Molecular and Structural

Endocrinology,

a section of the journal

Frontiers in Endocrinology

Received: 01 March 2019

Accepted: 03 July 2019

Published: 17 July 2019

Citation:

Berta E, Lengyel I, Halmi S, Zrínyi M, Erdei A, Harangi M, Páll D, Nagy EV and Bodor M (2019) Hypertension in

Thyroid Disorders.

Front. Endocrinol. 10:482.

doi: 10.3389/fendo.2019.00482
Arterial hypertension represents a major global health concern; more than one fourth of the population is affected by high blood pressure. Albeit the underlying cause of the disease remains unclear in the vast majority of the cases, $\sim 10 \%$ are of secondary origin. Endocrine disorders are common illnesses and some of them may lead to elevated blood pressure, among which thyroid diseases are of high prevalence and often overlooked, especially in mild cases. Overt and subclinical hyper- and hypothyroidism can both lead to (mostly mild) hypertension; however, the underlying mechanisms are only partially understood. The results of clinical studies are often controversial. During the past decades, some genetic mutations in the hypothalamus-pituitary-thyroid axis with cardiovascular consequences were revealed. Atherosclerotic changes resulting from lipid abnormalities due to thyroid dysfunction also affect the vasculature and can cause elevated blood pressure. The review gives a synopsis of our knowledge how thyroid hormone metabolism and functional thyroid diseases affect the cardiovascular system, their negative impact and causative role in the development of hypertension.

Keywords: blood pressure, endocrine, hypertension, hypothyroidism, hyperthyroidism, arterial stiffness, cardiovascular risk, thyroid

\section{INTRODUCTION}

Hypertension affects $26.4 \%$ of the global adult population remaining the leading preventable risk factor for premature death and disability worldwide $(1,2)$. Besides the majority of patients with primary (essential) hypertension, a subgroup of $\sim 10 \%$ of patients is affected by secondary hypertension. Among the underlying diseases several are of endocrine origin and thyroidal impairments represent an even smaller percentage of the secondary hypertension cases; their incidence and form of presentation varies with age and studied population (3). Hypertension may be the initial clinical presentation for at least 15 endocrine disorders (4), including overt and subclinical hyperthyroidism and hypothyroidism. The correction of thyroid dysfunction may normalize blood pressure (BP) in most cases, therefore checking thyroid function is essential during the workup for hypertension.

Thyroid dysfunction, both hypo- and hyperthyroidism may increase the risk of hypertension $(5,6)$. Hypothyroidism should be considered as a graded phenomenon with a wide variety of clinical conditions from subclinical hypothyroidism to myxedema. Subclinical hypothyroidism is a combination of serum thyrotropin (TSH) above the upper reference limit and normal free thyroxine (fT4) and free triiodothyronine (fT3) levels (7). This definition is only applicable in the absence of other acute or chronic recent or ongoing severe illness, assuming a stable thyroid function weeks or more before the evaluation and a normally functioning 
hypothalamic-pituitary-thyroid axis. Overt hypothyroidism is characterized by an elevated TSH, usually above $10 \mathrm{mIU} / \mathrm{L}$, in combination with reduced circulating fT4 and fT3 levels.

While the most common cause of hypothyroidism had been environmental iodine deficiency for centuries, the situation has changed and the population became iodine sufficient or only mildly deficient. Since then, the leading causes of hypothyroidism are chronic autoimmune thyroid diseases (AITDs). Hashimoto's thyroiditis is 5-10 times more common in women than in men, characterized by an increased prevalence with age $(8,9)$. In AITDs the thyroid gland is infiltrated by sensitized $\mathrm{T}$ lymphocytes, while circulating thyroid autoantibodies can be detected as a consequence of presumably inherited defect in immune surveillance. Furthermore, hypothyroidism may occur as a consequence of radioiodine or surgical treatment for hyperthyroidism, benign nodular thyroid disease or thyroid cancer, and after external beam radiation for head and neck malignancies. Pharmacological treatment, in most of the cases administration of the iodine-containing antiarrhythmic agent amiodarone, lithium, or immune response modulators, such as interferon alfa can result in the development of thyroiditis and thyroid dysfunction; relatively new iatrogenic causes of hypothyroidism are tyrosine kinase inhibitors and PD-1 inhibitors, sunitinib, and nivolumab, respectively. Sunitinib induces hypothyroidism via reduction of glandular vascularization and induction of type 3 deiodinase enzyme $(9,10)$. The mechanism by which nivolumab impairs the thyroid function is not entirely understood; the explanation might be a reduction in the immune tolerance to normal thyroid tissue antigens (11). Central causes of hypothyroidism are acquired or congenital of origin; pituitary or hypothalamic tumors (including craniopharyngiomas), inflammatory (lymphocytic or granulomatous hypophysitis) or infiltrative diseases, hemorrhagic necrosis (Sheehan's syndrome), or surgical and radiation treatment for pituitary or hypothalamic disease can stay in the background of insufficient production of bioactive TSH (9).

The reported prevalence rate of overt hypothyroidism is between 0.2 and $5.3 \%$ in Europe and $0.3-3.7 \%$ in the United States, most probably due to the differences in iodine intake (12). The incidence of subclinical hypothyroidism was found to be $7.5 \%$ in the Wickham study (13), while in the Colorado study $21 \%$ among women and $16 \%$ in men, respectively (14). The levels of circulating TSH and antithyroid autoantibodies increase with advancing age; according to the NHANES III data TSH levels above $4.5 \mathrm{mIU} / \mathrm{L}$ are present in $14 \%$ of the population aged 85 and above (8).

The most common causes of hyperthyroidism are autoimmune Graves' disease and multinodular goiter. Iatrogenic hyperthyroidism can be a consequence of iodine exposure during administration of iodine-containing drugs among which far the most important is amiodarone, or excess of levothyroxine replacement therapy. Immune response modulator therapy of cancers can lead to hypo- and less frequently hyperthyroidism (15). Subacute thyroiditis is a less frequent cause of hyperthyroidism. Iatrogenic subclinical hyperthyroidism is the declared aim of T4 therapy, and is a relatively frequent condition among patients with differentiated thyroid cancer after near-total thyroidectomy. Further, a few weeks of iatrogenic overt hypothyroidism is an alternative to recombinant TSH administration before radioiodine treatment and during follow-up, in accordance with international guidelines.

The prevalence of thyrotoxicosis among women is between 0.5 and $2 \%$, a 10 -fold female predominance is present. Subclinical hyperthyroidism is a condition of mild thyroid hormone excess defined by a serum TSH concentration below the lower reference limit and normal serum fT4 and fT3 concentrations. The same biochemical pattern may describe hypothalamic or pituitary disease, non-thyroidal illness, or the pharmacologic effect of TSH secretion inhibiting drugs. The prevalence of subclinical hyperthyroidism ranges from 0.5 to $6.3 \%$, with the highest established prevalence in individuals over 65 years; approximately half of the affected patients are on levothyroxine substitution (16).

Other relatively common thyroid diseases as multinodular goiter with euthyroidism and differentiated thyroid cancer have sparse impact on the cardiovascular system, and especially, the development of hypertension; however, a recently published meta-analysis found that hypertension significantly increases the risk of development of thyroid cancer (17).

This review focuses on the common functional thyroid disorders, hypo- and hyperthyroidism that have impact on the cardiovascular system and especially hypertension. The underlying causes of thyroid dysfunction are listed in Table 1.

\section{METABOLISM OF THYROID HORMONES AND THEIR EFFECTS ON THE CARDIOVASCULAR SYSTEM}

Triiodothyronine is the biologically active form of thyroid hormone derived from $5^{\prime}$-monodeiodination of thyroxine in all tissues outside of the thyroid gland, particularly the kidney, liver, and skeletal muscle. The basal metabolic rate is affected by fT3 via altering oxygen consumption, substrate requirements and tissue thermogenesis (4). Thyroid hormones have direct and indirect cellular effects on the cardiovascular system. In hyperthyroidism systemic vascular resistance decreases as fT3 dilates resistance arterioles of the peripheral circulation, which results in the fall of the effective arterial filling followed by stimulation of renin release and activation of the angiotensin-aldosterone axis (18).

Patients with hyperthyroidism present with increased heart rate, increased pulse amplitude, and increased cardiac output by up to $300 \%$, which resembles a state of increased adrenergic activity $(6,19)$, despite normal or low serum concentrations of catecholamines. Other hormonal factors are also affected: the levels of atrial natriuretic peptide, brain natriuretic peptide, endothelin-1 and the vasodilating polypeptide adrenomedullin are elevated in hyperthyroidism $(6,20)$. Thyroid hormone also stimulates erythropoietin secretion. Furthermore, T3 directly increases cardiac contractility, leading to widened pulse pressure $(18,20,21)$. The coexistence of ischemic or hypertensive heart disease in a thyroid patient may compromise the ability of the 
TABLE 1 | Causes of thyroid dysfuntions.

\begin{tabular}{|c|c|}
\hline Causes of hyperthyroidism & Causes of hypothyroidism \\
\hline Overfunction of the thyroid & Congenital \\
\hline Graves' disease & Thyroid dysgenesis \\
\hline Toxic adenoma & Dyshormonogenesis \\
\hline Toxic multinodular goiter & Deficiency of TRH/TSH \\
\hline lodine-induced hyperthyroidism & Acquired forms in adults \\
\hline TSH-mediated hyperthyroidism (TSH producing pituitary adenoma) & Primary hypothyroidism \\
\hline Trophoblastic disease and germ cell tumors & Hashimoto thyroiditis \\
\hline Destructive thyroid diseases (thyroiditises) & latrogenic causes: \\
\hline Subacute thyroiditis & - thyroidectomy \\
\hline Hashimoto thyroiditis & - radioidine therapy \\
\hline \multicolumn{2}{|l|}{ Silent thyroiditis } \\
\hline Post-partum thyroiditis & Drugs (iodine, lithium, amiodarone, thyreostatic therapy, interferon, tyrosin kinase \\
\hline lodine-induced thyroiditis & inhibitors, anti-CD52 monoclonal antibody etc.) \\
\hline Ectopic hyperthyroidism & Infiltrative disease \\
\hline Metastatic follicular thyroid cancer & Environmental exposures \\
\hline Struma ovarii & Consumptive hypothyroidism \\
\hline Exogenous hyperthyroidism & Central (secondary and tertiary) hypothyroidism \\
\hline "Hamburger" hyperthyroidism & Resistance to thyroid hormone \\
\hline Overdosage of thyroxin & Resistance to thyrotropin and thyrotropin-releasing hormone \\
\hline
\end{tabular}

myocardium to respond to the increased metabolic needs in hyperthyroidism and demands caution from the clinician (6).

The mortality of patients with hyperthyroidism was found to be increased by $20 \%$, and the major causes of death are due to cardiovascular origin (22). The level of cardiac T3, as myocyte intracellular deiodinase activity is not significant, is fundamental in maintaining cardiac morphology and function in adult life via genomic and non-genomic effects. The expression of the main structural and regulatory genes is regulated by T3. Positively regulated genes as $\alpha$-myosin heavy chain, sarcoplasmic reticulum $\mathrm{Ca}^{2+}$-ATPase, $\beta 1$-adrenergic receptor, atrial natriuretic hormone and voltage-gated potassium channels also contribute to the development of cardiac output increase observed in hyperthyroidism (21). In contrary, the inhibitor of sarcoplasmic reticulum $\mathrm{Ca}^{2+}$-ATPase phospholamban is negatively regulated, as well as the genes of $\beta$-myosin heavy chain, adenylyl cyclase catalytic subunits, $\mathrm{Na}^{+} / \mathrm{Ca}^{2+}$ exchanger and thyroid hormone receptor $\alpha 1$ (21). Non-genomic effects of T3 can develop rapidly in the cardiovascular system not requiring thyroid hormone response element-mediated transcriptional events and altering or modulating the effects of genomic mechanisms (23).

According to earlier studies heart failure develops in 6$16 \%$ of patients with hyperthyroidism. Patients with preexisting hypertension or with risk factors for coronary artery disease have a more pronounced risk for developing hemodynamic changes leading to chronic heart failure. A relatively frequent complication of hyperthyroidism, atrial fibrillation, is an independent predictor for the development of chronic heart failure $(24,25)$.
Arterial stiffness is increased in hyperthyroidism (26) due to the effect of thyroxin on vascular smooth muscle and endothelial cells via genomic and non-genomic action targeting membrane ion channels and endothelial nitric oxide synthesis (27). In addition, the Calcium/ Calmodulin-dependent kinase IV (CaMKIV), which is known to be a major thyroid hormone target gene during brain development, plays an important role in blood pressure regulation through the control of endothelial nitric oxide synthase (eNOC) activity (28-30).

The hemodynamic effects of hypothyroidism are opposite to those of hyperthyroidism, although the clinical manifestations are less obvious with bradycardia being the most common sign accompanied by mild hypertension and a narrowed pulse pressure. Bradycardia, decreased ventricular filling and cardiac contractility together lead to low cardiac output. An increase in the systemic vascular resistance and slowed ventricular diastolic relaxation and filling are present. The decreased metabolic rate leads to a decline in peripheral oxygen demand, consequently heart failure is a rare clinical manifestation of hypothyroidism (31). Elevated diastolic blood pressure is present in $\sim 30 \%$ of patients with overt hypothyroidism. Cardiac contractility and output decreases leading to a narrowed pulse pressure. In hypothyroidism renin release is decreased with an increased salt sensitivity. The consequent renal sodium reabsorption leads to an expansion of blood volume by $5.5 \%(5,21,31)$.

We have previously shown that in patients who had undergone thyroidectomy for differentiated thyroid cancer, increased aortic stiffness and impaired diastolic function can be detected during induced overt hypothyroidism, which is part of the diagnostic follow-up procedure (32). 
Several clinical data suggest that autoimmune thyroid disease may be responsible for the development of primary pulmonary hypertension in both hyper- and hypothyroidism; therefore in pulmonary hypertension $(\mathrm{PH})$ thyroid function should be evaluated $(33,34)$.

The effects of the functional thyroid disorders on the cardiovascular system leading to hypertension are summarized in Figure 1.

\section{GENETIC BACKGROUND OF THYROID FUNCTION AFFECTING BLOOD PRESSURE}

While a normal TSH and consequently fT4 and fT3 within the physiological range are essential in growth, differentiation and maintenance of adequate function of all human organs, several genetic defects have been evaluated and described in the route of thyroid hormone signaling during the past decade, including those with mutations in thyroid hormone transporters and receptors (35). According to novel studies, even minor changes in the thyroid hormone levels can affect bone mineral density (36), mental status (37), and can also lead to impaired metabolism (38), and increased cardiovascular risk (39). While the levels of the serum thyroid hormones show marked inter-individual variability, there is no significant intra-individual variability, as $\mathrm{TSH}$ values change very little during time (40). Based on these results a conclusion can be made that each individual has a unique thyroid set-point, defined by genetic and environmental factors such as iodine intake and smoking $(41,42)$.

The genetic pattern of the hypothalamic-pituitary-thyroid axis involves numerous genes with rare high-penetrance variants and common low-penetrance forms, mutations and polymorphisms, respectively. Several mutations of the hypothalamic-pituitarythyroid axis were described to date and found responsible for impaired thyroid function $(43,44)$. A large number of new genes were identified during the last decade that affect the hypothalamic-pituitary-thyroid axis, some of which are responsible for thyroid dysfunction and consequently affect different organs and present risk factors for the development of different diseases, including hypertension.

Thyroid dysfunction is rarely attributed to single gene mutations. Numerous studies were performed in the last 2 years to reveal genetic variants presenting with polymorphisms associated with thyroid impairment and altered function. These encompass both linkage and candidate gene analyses targeting the hypothalamus-pituitary-thyroid pathway. A detailed overview of genes affecting the thyroid axis is found elsewhere (35). A few polymorphisms were found to be associated with blood pressure; however, the results remain controversial. A couple of type II iodothyronine deiodinase (DIO2) gene mutations were found to cause hypertension in middle-aged patients with euthyroidism (45). Interestingly, these variants did not cause any changes in the circulating TSH or free thyroid hormone levels $(46,47)$. These results were not confirmed by other clinical studies $(48,49)$. A mutation in the thyrotropin releasing hormone receptor gene was characterized to be associated with an increased risk of essential high blood pressure (50). The findings regarding gene mutations affecting blood pressure values remain controversial and need further evaluation.

\section{HYPERTENSION AND INCREASED CARDIOVASCULAR RISK IN OVERT HYPERTHYROIDISM}

Hyperthyroidism is accompanied by cardiovascular complications (cardiac arrhythmias, hypercoagulopathy, stroke, and pulmonary embolism) in a significant number of cases, leading to an increase in short-term morbidity and longterm morbidity and mortality. Brandt et al. found a significant $20 \%$ increase in mortality in patients with hyperthyroidism in their meta-analysis based on seven studies (22).

The excess of T3 leads to metabolic and hemodynamic changes: metabolic rate, cardiac preload, and ventricular contractility increases while systemic vascular resistance decreases, causing an increased cardiac output and hypertension, as discussed above.

The highest risk of coronary heart disease mortality and atrial fibrillation is noted when serum TSH is below $0.10 \mathrm{mIU} / \mathrm{l}(51)$.

Hemodynamic changes affect not only the left cardiac output, since pulmonary hypertension may also be present in patients with hyperthyroidism due to Graves-disease or nodular goiter (33). Pulmonary hypertension was found to be the most common complication in a study which investigated hyperthyroid patients by echocardiography (52). The prevalence of pulmonary hypertension was detected to be relatively high among hyperthyroid patients, varying between 36 and $65 \%$, although mild and asymptomatic cases were found to be the most common $(53,54)$.

In the pharmacological treatment of systolic secondary hypertension caused by hyperfunction of the thyroid gland, besides reaching euthyroidism, non-selective beta-blockers are often preferred, for controlling the concomitant tachycardia and tremor effectively and blocking the peripheral T4 to T3 conversion (55).

The increased cardiovascular mortality among patients with hyperthyroidism may be as well the consequence of shared genetic or environmental factors, based on the pronounced familial aggregation of hyperthyroidism, cardiovascular disease, lifespan, and smoking habits (22).

Our group previously found that there is an increase in the aortic stiffness in combination with decreased diastolic function in patients with subclinical hyperthyroidism on levothyroxine suppression therapy after total thyroidectomy due to differentiated thyroid cancer (32).

A study found that patients with hyperthyroidism and normal blood pressure during ambulatory blood pressure monitoring (ABPM) had higher systolic blood pressure than euthyroid normotensive participants. The successful treatment of hyperthyroidism resulted in normalization of systolic blood pressure. The nocturnal decrease in blood pressure did not differ from that of normal subjects (56). 

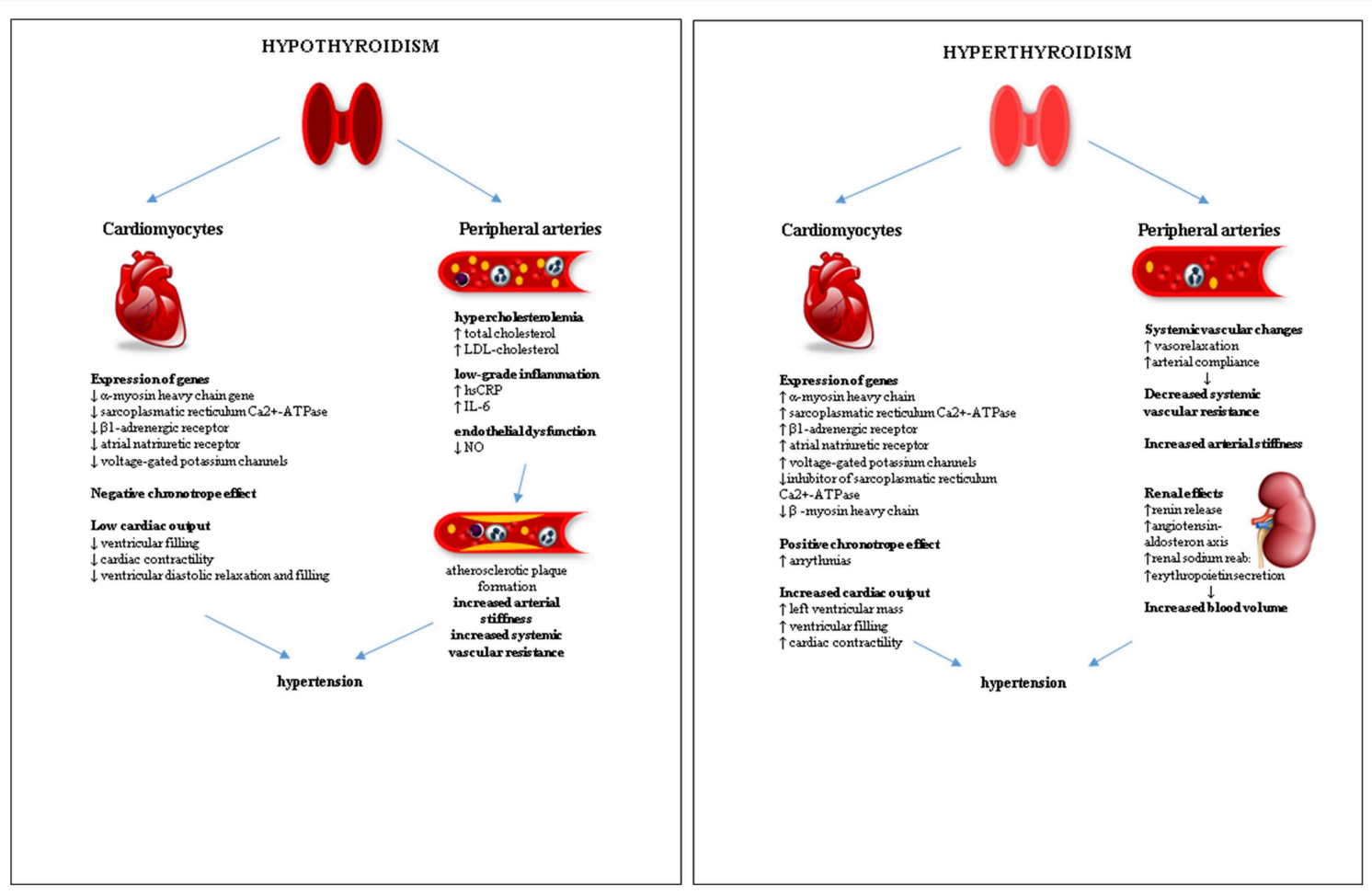

FIGURE 1 | Effects of functional thyroid disorders on the cardiovascular system leading to hypertension.

In a recently published study Lillevang-Johansen et al. investigated the association between hyperthyroidism and the occurrence of cardiovascular (CV) events among treated and untreated hyperthyroid patients (57). The real-world data of this study revealed the impact of varying thyroid status on cardiovascular events: untreated and insufficiently treated hyperthyroid patients had increased cardiovascular risk. According to the data of more than 275,000 individuals followedup for hyperthyroidism, sufficiently controlled thyrotoxicosis did not increase cardiovascular risk. After an adjustment for main cardiovascular risk factors such as hypertension, diabetes and hyperlipidemia, the findings were not significantly affected, suggesting that elevated thyroid hormone levels are playing a major role in the increase of $\mathrm{CV}$ risk (57). These findings suggest that careful monitoring of treatment and maintaining euthyroidism is fundamental in the prevention of $\mathrm{CV}$ events among patients with hyperthyroidism.

\section{HYPERTENSION AND INCREASED CARDIOVASCULAR RISK IN SUBCLINICAL HYPERTHYROIDISM}

Subclinical hyperthyroidism is defined as a subnormal serum TSH value accompanied by T4 and T3 within the normal reference range. The change in thyroid function needs to be evaluated and confirmed by a second laboratory measurement after 3-6 months (58). The prevalence of subclinical hyperthyroidism can be detected more frequently in iodine depleted areas and increases with advancing age (58). According to the Third National Health and Nutrition Examination Survey (NHANES III) $0.7 \%$ of 16,533 people were reported to have subclinical hyperthyroidism $(\mathrm{TSH}<0.1 \mathrm{mU} / \mathrm{L})$; these subjects were not taking thyroid medication (8). Subclinical hyperthyroidism can be classified into two categories: Grade 1 , with a mild decrease of serum TSH (0.1-0.4 mIU/L), and Grade 2, with a more marked TSH decrease (TSH below 0.1 $\mathrm{mIU} / \mathrm{L})(59)$.

The long exposure of the heart to subclinical hyperthyroidism leads to an altered cardiac morphology and function. As a consequence, left ventricular function changes: systolic function is enhanced, while diastolic function becomes impaired, a slowed myocardial relaxation is present resulting in an increase of left ventricular mass (60); as well as increased heart rate and arrhythmias, such as atrial fibrillation (61).

Although lipid profile is not affected unfavorably in subclinical hyperthyroidism, endothelial dysfunction and increased thrombogenicity is present $(59,62,63)$.

A meta-analysis with more than 25,000 participants proved that subclinical hyperthyroidism is associated with increased risk of coronary artery disease events and coronary artery disease mortality, and also with elevated total mortality. The risk for mortality due to coronary artery disease and atrial fibrillation was more prominent in Grade 2 subclinical hyperthyroidism (51).

In the Rotterdam study involving more than 9,000 participants, the risk of cardiovascular mortality increased 
in a linear manner with subclinical hyperthyroidism and free T4 levels close to the upper limit of the reference range compared to those with free T4 levels close to the lower limit (64). A large systematic review with data from more than 70,000 people found that subclinical hyperthyroidism was associated with an increased risk of total mortality, heart failure, atrial fibrillation and coronary artery disease mortality in patients with Grade 2 subclinical hyperthyroidism (65).

Besides these changes in the cardiovascular risk due to subclinical hyperthyroidism, prospective cohort studies failed to show significant association between subclinical hyperthyroidism and hypertension $(66,67)$. Due to the increased risk for the development of cardiovascular diseases and mortality, there is a wide agreement among specialists that treatment of patients with Grade 2 subclinical hyperthyroidism should be initiated (59).

\section{ATHEROSCLEROSIS AND HYPOTHYROIDISM}

Thyroid hormones affect biochemical and molecular mechanisms of lipid homeostasis resulting in a variable phenomenon of dyslipidemia (68) mostly characterized by high serum concentrations of total and low-density lipoprotein (LDL) cholesterol and normal or even elevated high-density lipoprotein (HDL) cholesterol levels. Furthermore, high serum concentrations of triglycerides, intermediate-density lipoproteins, apolipoprotein $\mathrm{A}$ and apolipoprotein $\mathrm{B}$ are frequently observed (69-71). The primary mechanism in the background of hypercholesterolemia is the accumulation of LDL cholesterol due to reduction in the number and activity of the cell-surface LDL receptors resulting in decreased hepatic LDL catabolism. In addition to the direct effect of T3 on the promoter region of the LDL receptor gene, sterol regulatory element-binding protein-2 (SERBP-2) gene is also regulated by $\mathrm{T} 3$, resulting in the altered transcription of 3-hydroxy-3methylglutaryl coenzyme A (HMG-CoA) reductase and LDL receptor genes $(68,71,72)$. Thyroid hormones also increase the activity of cholesteryl ester transfer protein, hepatic lipase, lipoprotein lipase, and lecithin-cholesterol acyltransferase $(56,61)$. Although a substantial number of studies indicated a beneficial response in patients with TSH levels between 2.5 and 4.5 concerning atherosclerosis risk factors such as atherogenic lipid parameters, impaired endothelial function, and intima media thickness $(9,73)$, TSH has no defined cutoff threshold regarding cardiovascular prevention and atherosclerosis (68).

A study of more than 30,000 patients showed similar results: increased LDL, non-HDL cholesterol and triglycerides and decreased HDL with high-normal TSH levels still in the reference range (74). Since the thyroid hormones have known regulatory effect on the lipid metabolism and consequently on blood pressure, their impact on the cardiovascular system may be partially explained by these mechanisms $(75,76)$. Another large prospective study involving more than 14,000 participants with normal TSH levels at start and followed for 11 years found that high-normal TSH levels were predictive for moderately higher blood pressure in the future. Moreover, $1 \mathrm{mU} / \mathrm{L}$ elevation in the TSH values resulted in about $2 \mathrm{mmHg}$ elevation in the systolic blood pressure, 1-2 $\mathrm{mmHg}$ increase in the diastolic blood pressure and $0.1 \mathrm{mmol} / \mathrm{L}$ rise in non-HDL cholesterol and triglyceride values (77).

Hypothyroidism being one of the most common secondary causes of dyslipidemia (78) is clearly associated with an increased risk for atherosclerotic cardiovascular disease owing to its metabolic and hemodynamic effects (79). Atherosclerosis develops in patients with hypothyroidism as a consequence of multiple mechanisms including hyperlipidemia, hypercoagulable state, endothelial dysfunction and increased arterial stiffness which leads to arterial hypertension $(80,81)$.

The atherogenic lipid changes in hypothyroidism, similarly to the ones in BP values, appear to develop rapidly, as seen in individuals with a hypothyroidism only 3 weeks following thyroidectomy due to non-toxic multinodular goiter (82). Even low normal fT4 concentrations have been associated with a more atherogenic lipid profile (83). In a study involving more than 5,000 participants a significant association has been described between LDL, total cholesterol and TSH levels ranging 3.5$10 \mathrm{mU} / \mathrm{L}$ (84). Total cholesterol and LDL levels decreased in a crossover study after $100 \mu \mathrm{g}$ levothyroxine supplementation of the subjects having TSH values greater than $6.1 \mathrm{mU} / \mathrm{L}$ (85). The same result was observed in another study conducted among individually substituted patients with TSH greater than $8 \mathrm{mU} / \mathrm{L}(68,86)$.

Besides dyslipidemia, changes in coagulation parameters are described in thyroid disorders being partly responsible for atherogenic changes. Decreased platelet count, aggregation and agglutination, von Willebrand factor antigen and activity, decreased levels of several coagulation factors such as factor VII, VIII, IX, XI, and plasminogen activator-1 can be detected in overt hypothyroidism leading to hypercoagulability. In subclinical hypothyroidism and autoimmune thyroid disease increased fibrinogen level, factor VII level and activity, and plasminogen activator inhibitor-1 level have been detected rendering a tendency toward a hypercoagulable state $(87,88)$. The mechanisms underlying the development of the changes in coagulation parameters in hypothyroidism are not well understood. A possible explanation might be the direct effect of the thyroid hormones. However, it is still unclear whether the thyroid hormone deficiency or the elevated TSH levels, or both, are responsible for the alteration in the coagulation parameters (87).

Furthermore, the association between hypothyroidism and defects in the secretion of endothelium-dependent dilation factors is well known $(89,90)$. Endothelial cell TSH receptor induces multiple effects including the down-regulation of antiinflammatory factors such as tumor necrosis factor- $\alpha$ and interleukine- 6 , in addition to the induction of angiogenesis (vascular endothelial growth factor, VEGF), and leukocyte adhesion (intercellular adhesion molecule-1, ICAM-1 and Eselectin). Elevated expression of leukocyte adhesion molecules is related to endothelial dysfunction, which is believed to be an early step in the development and progression of atherosclerosis. Assessment of endothelial dysfunction, as an early biomarker, is helpful in predicting cardiovascular risk and evaluating the 
outcome of treatment (91). Flow-mediated dilation of the brachial artery is a functional test of the capacity of increased blood flow provoked by the release of endothelial $\mathrm{NO}$ and other vasodilator mediators, following induced ischemia, therefore, is an accepted early method for non-invasive assessment of systemic endothelial function (92). Flow-mediated dilation was found to be impaired not only in patients with mild hypothyroidism but also in subjects with "high-normal" serum TSH levels (93). Another study also reported that patients with subclinical hypothyroidism had significantly lower flowmediated dilation values (94).

Despite the above mentioned data, the association of subclinical hypothyroidism and atherosclerosis is still debated, although hyperlipidemia is usually present $(79,95)$. Carotid artery intima-media thickness measurement remains a longstanding and reliable diagnostic modality used to assess vascular morbidity at an early stage (96). A recent study revealed that carotid artery intima-media thickness is significantly higher in patients with both overt and subclinical hypothyroidism compared with normal control subjects (97).

Central arterial stiffness is positively associated with systolic hypertension, coronary artery disease, stroke, and heart failure, which are the leading causes of mortality in developed countries. Central arterial stiffening or reduced arterial compliance leads to augmented central blood pressure, increased cardiac afterload, and is an independent predictor of cardiac events (98). A previous study confirmed that hypothyroidism is associated with increased augmentation of central aortic pressure and central arterial stiffness. Furthermore, these abnormalities are reversed after adequate T4 replacement (80). Arterial stiffness was also increased in subclinical hypothyroidism and improved with Lthyroxine treatment (99).

The above detailed impairment in the lipid metabolism due to hypothyroidism may contribute to the development or progression of hypertension. In addition, patients affected by hypothyroidism may have other concomitant cardiovascular diseases and consequently their summed effect on the blood pressure may be even more accentuated.

\section{HYPERTENSION IN OVERT HYPOTHYROIDISM}

A high prevalence of diastolic hypertension had been found in patients above 50 years of age with overt hypothyroidism whose blood pressure was normalized after adequate thyroid hormone replacement therapy (100). However, hypothyroidism as a cause of hypertension is often overlooked. In an early study Saito et al. found a 3-fold higher prevalence of diastolic hypertension in hypothyroidism than in age-matched patients without thyroid disorder using the World Health Organization's (WHO) earlier used criteria for hypertension, namely blood pressure $>160 / 95 \mathrm{mmHg}(100,101)$. According to the current ESC guidelines for the treatment of hypertension, in-office systolic blood pressure (SBP) values $\geq 140 \mathrm{mmHg}$ and/or diastolic blood pressure (DBP) values $\geq 90 \mathrm{mmHg}$ define hypertension based on evidence from multiple randomized clinical trials proving that treatment of patients with these BP values is beneficial (102).

Masked hypertension, defined as a normal in-office blood pressure in spite of higher values detected during an active day, can be found during evaluation via ambulatory blood pressure monitoring (ABPM) or home blood pressure monitoring (HBPM); masked hypertension is present in $\sim 15 \%$ of untreated patients. The prevalence of this condition is greater among younger men, who are affected by higher levels of anxiety and job stress. Furthermore, habits like smoking, alcohol consumption and more pronounced physical activity are more common among them (103). Recently published data has suggest that many individuals with masked hypertension present with a higher left ventricular mass index, therefore a higher cardiovascular risk, in the detection of which ABPM seems more efficient than HBPM (104). In a recently published pilot study, the occurrence of masked hypertension was evaluated among patients with overt and subclinical hypothyroidism using 24-h ABPM; a significantly higher prevalence of masked hypertension was found in both groups compared to controls with euthyroidism, which suggests the existence of elevated cardiovascular risk in hypothyroidism, especially in young male patients with autoimmune thyroiditis (105).

Positive association of serum TSH levels with arterial blood pressure was demonstrated through a cross-sectional analysis of pooled data from five population-based studies in adults (106). The association was present in the full range of TSH and even within the reference range, while positive correlation was limited to prevalent hypertension, and not in a 5-year change of blood pressure or incident hypertension (106). In patients who underwent thyroid surgery due to differentiated thyroid cancer and had overt hypothyroidism before radioiodine therapy, an elevation in nocturnal systolic, mean and diastolic blood pressure was found; also, an increased number of non-dippers were found among these subjects (107).

\section{BLOOD PRESSURE CHANGES IN SUBCLINICAL HYPOTHYROIDISM}

Hypothyroidism has been generally considered as a cardiovascular risk factor, as discussed above, stressing the need of routine screening for thyroid function especially among female patients with coronary heart disease or patients with known cardiovascular risk factors (108). Subclinical hypothyroidism is a common entity, characterized by elevated TSH-levels and fT4 and fT3 levels in the normal range.

The association between elevated blood pressure and overt thyroid disorders has been thoroughly investigated and wellestablished, while the question whether subclinical changes in the thyroid function present potential risk for the development and maintenance of hypertension are still under debate. Some studies detected positive correlations of subclinical hypothyroidism and hypertension in women $(109,110)$; however, the same results were not confirmed in men $(110,111)$. A number of clinical studies assessed the relationship between subclinical thyroid dysfunction, both hypo and hyperthyroidism, and 
endothelial dysfunction (112), arterial wall thickening (80, 99, 113), atrial fibrillation (114), and left ventricular hypertrophy (115). A study involving more than 10.000 children and adolescents found a positive correlation between elevated serum TSH levels and both systolic and diastolic blood pressure; however, this correlation was not established with hypertension (116). Upon these findings, one can presume an association between subclinical hypothyroidism and elevated risk for the development of hypertension.

In a large, population-based study with more than 30,000 participants the thyrotropin levels within the normal range were significantly correlated with the arterial blood pressure and hypertension as well in both genders; however, TSH levels above the upper limit presented positive association in women only (109). One possible explanation for this discrepancy may be that TSH levels were measured only in half of the male participants and $100 \%$ of female patients. Furthermore, these inconsistent data may also be affected by the iodine intake of the studied population; the range of TSH level may differ upon the iodine supply of the studied region (117). Studies that were conducted in regions with iodine excess like Far East Asia failed to find any correlation between blood pressure and TSH values within the normal range; these regions have higher thyrotropin reference range limits $(110,118)$. On the contrary, several studies performed in regions characterized by mild to moderate iodine deficiency or even sufficient iodine intake showed a positive correlation between TSH level and blood pressure values $(106,119)$. The differences observed in the results, however, may be partially due to the higher prevalence of hypertension in Far East Asia compared to Europe and the alternate screening and treatment methods used in these regions (120).

Overall, the data from several studies and pooled analyses suggest that the correlation between high serum thyrotropin levels and blood pressure changes might be time-dependent and cannot predict the further development of hypertension and might occur only during an actual TSH elevation (106).

\section{REFERENCES}

1. Kearney PM, Whelton M, Reynolds K, Muntner P, Whelton PK, He J. Global burden of hypertension-analysis of worldwide data. Lancet. (2005) 365:217-23. doi: 10.1016/S0140-6736(05)17741-1

2. Forouzanfar MH, Alexander L, Bachman VF, Biryukov S, Brauer M, Casey $\mathrm{D}$, et al. Global, regional, and national comparative risk assessment of 79 behavioural, environmental and occupational, and metabolic risks or clusters of risks in 188 countries, 1990-2013: a systematic analysis for the Global Burden of Disease Study 2013. Lancet. (2015) 386:2287-323. doi: 10.1016/S0140-6736(15)00128-2

3. Charles L, Triscott J, Dobbs B. Secondary hypertension: discovering the underlying cause. Am Fam Phys. (2017) 96:453-461.

4. Young WF, Calhoun DA, Lenders JWM, Stowasser M, Textor SC. Screening for endocrine hypertension: an endocrine society scientific statement. Endocr Rev. (2017) 38:103-22. doi: 10.1210/er.201700054

5. Cappola AR, Ladenson PW. Hypothyroidism and atherosclerosis. J Clin Endocrinol Metab. (2003) 88:2438-44. doi: 10.1210/jc.2003030398
In a recently published meta-analysis the effect of levothyroxine replacement therapy on blood pressure in subclinical hypothyroidism was investigated. The summed results of 10 randomized clinical trials showed that after levothyroxine therapy systolic blood pressure was reduced significantly. A subgroup analysis suggested that the systolic blood pressure lowering effect was more accentuated in patients with higher TSH levels. In 19 prospective follow-up studies both systolic and diastolic blood pressure values decreased significantly after levothyroxine initiation (121).

\section{CONCLUSIONS}

Alterations of thyroid function may result in changes in blood pressure values as well as other traditional cardiovascular risk factors, leading to an increased cardiovascular risk, which is mild in most cases, although hyperthyroidism represents a significant elevation of cardiovascular mortality risk. The delayed clinical recognition of subclinical forms of thyroid dysfunction, i.e., subclinical hypo and hyperthyroidism has unfavorable cardiovascular effects. Available data suggest that, concerning cardiovascular risks, early diagnosis, and treatment of even mild forms of functional thyroid disorders might be beneficial in the vast majority of the patients. However, overtreatment should be avoided, and age-related or individual variances of pituitarythyroid set-points have to be respected.

\section{AUTHOR CONTRIBUTIONS}

All authors listed have made a substantial, direct and intellectual contribution to the work, and approved it for publication.

\section{FUNDING}

This research was supported by GINOP-2.3.2-15-2016-00005 project. The project is co-financed by the European Union under the European Regional Development Fund.

6. Prisant LM, Gujral JS, Mulloy AL. Hyperthyroidism: a secondary cause of isolated systolic hypertension. J Clin Hypertens. (2006) 8:596-9. doi: 10.1111/j.1524-6175.2006.05180.x

7. Surks MI, Ortiz E, Daniels GH, Sawin CT, Col NF, Cobin RH, et al. Subclinical thyroid disease: scientific review and guidelines for diagnosis and management. JAMA. (2004) 291:228-38. doi: 10.1001/jama.291.2.228

8. Hollowell JG, Staehling NW, Flanders WD, Hannon WH, Gunter EW, Spencer CA, et al. Serum TSH, T(4), and thyroid antibodies in the United States population (1988 to 1994): National Health and Nutrition Examination Survey (NHANES III). J Clin Endocrinol Metab. (2002) 87:48999. doi: 10.1210/jc.87.2.489

9. Garber JR, Cobin RH, Gharib H, Hennessey J V, Klein I, Mechanick JI, et al. Clinical practice guidelines for hypothyroidism in adults : cosponsored by the American Association of Clinical Endocrinologists and the American Thyroid Association. Thyroid. (2012) 22:1200-35. doi: 10.1089/thy.2012.0205

10. Cooper DS. Clinical practice. subclinical hypothyroidism. N Engl J Med. (2001) 345:260-5. doi: 10.1056/NEJM200107263450406

11. Maekura $T$, Naito $M$, Tahara $M$, Ikegami $N$, Kimura $Y$, Sonobe $\mathrm{S}$, et al. Predictive factors of nivolumab-induced hypothyroidism in 
patients with non-small cell lung cancer. In Vivo. (2017) 31:1035-9. doi: 10.21873/invivo.11166

12. Taylor PN, Albrecht D, Scholz A, Gutierrez-Buey G, Lazarus JH, Dayan CM, et al. Global epidemiology of hyperthyroidism and hypothyroidism. Nat Rev Endocrinol. (2018) 14:301-16. doi: 10.1038/nrendo.2018.18

13. Vanderpump MPJ, Tunbridge WMG, French JM, Appleton D, Bates D, Clark F, et al. The incidence of thyroid disorders in the community: a twentyyear follow-up of the whickham survey. Clin Endocrinol. (1995) 43:55-68. doi: 10.1111/j.1365-2265.1995.tb01894.x

14. Canaris GJ, Manowitz NR, Mayor G, Ridgway EC. The colorado thyroid disease prevalence study. Arch Intern Med. (2000) 160:526-34. doi: 10.1001/archinte.160.4.526

15. Chalan P, Di Dalmazi G, Pani F, De Remigis A, Corsello A, Caturegli P. Thyroid dysfunctions secondary to cancer immunotherapy. J Endocrinol Invest. (2018) 41:625-38. doi: 10.1007/s40618-017-0778-8

16. Garg A, Vanderpump MPJ. Subclinical thyroid disease. Br Med Bull. (2013) 107:101-16. doi: 10.1093/bmb/ldt024

17. Yin DT, He H, Yu K, Xie J, Lei $\mathrm{M}, \mathrm{Ma} R$, et al. The association between thyroid cancer and insulin resistance, metabolic syndrome and its components: a systematic review and meta-analysis. Int J Surg. (2018) 57:66-75. doi: 10.1016/j.ijsu.2018.07.013

18. Danzi S, Klein I. Thyroid disease and the cardiovascular system. Endocrinol Metab Clin North Am. (2014) 43:517-28. doi: 10.1016/j.ecl.2014.02.005

19. Levey GS, Klein I. Catecholamine-thyroid hormone interactions and the cardiovascular manifestations of hyperthyroidism. Am J Med. (1990) 88:6426. doi: 10.1016/0002-9343(90)90533-J

20. Danzi S, Klein I. Thyroid hormone and blood pressure regulation. Curr Hypertens Rep. (2003) 5:513-520. doi: 10.1007/s11906-003-0060-7

21. Klein I, Danzi S. Thyroid disease and the heart. Circulation. (2007) 116:172535. doi: 10.1161/CIRCULATIONAHA.106.678326

22. Brandt F, Green A, Hegedüs L, Brix TH. A critical review and meta-analysis of the association between overt hyperthyroidism and mortality. Eur J Endocrinol. (2011) 165:491-7. doi: 10.1530/EJE-11-0299

23. Davis PJ, Goglia F, Leonard JL. Nongenomic actions of thyroid hormone. Nat Rev Endocrinol. (2016) 12:111-21. doi: 10.1038/nrendo.2015.205

24. Yue WS, Chong BH, Zhang XH, Liao SY, Jim MH, Kung AWC, et al. Hyperthyroidism-induced left ventricular diastolic dysfunction: Implication in hyperthyroidism-related heart failure. Clin Endocrinol. (2011) 74:636-43. doi: 10.1111/j.1365-2265.2011.03981.x

25. Siu C, Yeung C, Lau C, Kung AWC, Tse H. Incidence, clinical characteristics and outcome of congestive heart failure as the initial presentation in patients with primary hyperthyroidism. Heart. (2007) 93:483-7. doi: 10.1136/hrt.2006.100628

26. Palmieri EA, Fazio S, Palmieri V, Lombardi G, Biondi B. Myocardial contractility and total arterial stiffness in patients with overt hyperthyroidism: acute effects of B1-adrenergic blockade. Eur J Endocrinol. (2004) 150:757-62. doi: 10.1530/eje.0.1500757

27. Vargas F, Moreno JM, Rodríguez-Gómez I, Wangensteen R, Osuna A, Alvarez-Guerra M, et al. Vascular and renal function in experimental thyroid disorders. Eur J Endocrinol. (2006) 154:197-212. doi: 10.1530/eje.1.02093

28. Santulli G, Cipolletta E, Sorriento D, Del Giudice C, Anastasio A, Monaco S, et al. CaMK4 gene deletion induces hypertension. J Am Heart Assoc. (2012) 1:e001081. doi: 10.1161/JAHA.112.001081

29. Levy D, Larson MG, Benjamin EJ, Newton-Cheh C, Wang TJ, Hwang SJ, et al. Framingham Heart Study 100K Project: genome-wide associations for blood pressure and arterial stiffness. BMC Med Genet. (2007) 8:S3. doi: 10.1186/1471-2350-8-S1-S3

30. Sabah KMN, Chowdhury AW, Islam MS, Cader FA, Kawser S, Hosen MI, et al. Graves' disease presenting as bi - ventricular heart failure with severe pulmonary hypertension and pre-eclampsia in pregnancy - a case report and review of the literature. BMC Res Notes. (2014) 7:814. doi: 10.1186/1756-0500-7-814

31. Danzi S, Klein I. Thyroid hormone and the cardiovascular system. Med Clin North Am. (2012) 96:257-68. doi: 10.1016/j.mcna.2012.01.006

32. Gazdag A, Nagy EV, Erdei A, Bodor M, Berta E, Szabó Z, et al. Aortic stiffness and left ventricular function in patients with differentiated thyroid cancer. $J$ Endocrinol Invest. (2015) 38:133-42. doi: 10.1007/s40618-014-0143-0
33. Marvisi M, Zambrelli P, Brianti M, Civardi G, Lampugnani R, Delsignore R. Pulmonary hypertension is frequent in hyperthyroidism and normalizes after therapy. Eur J Intern Med. (2006) 17:267-71. doi: 10.1016/j.ejim.2005.11.023

34. Paran Y, Nimrod A, Goldin Y, Justo D. Pulmonary hypertension and predominant right heart failure in thyrotoxicosis. Resuscitation. (2006) 69:339-41. doi: 10.1016/j.resuscitation.2005.09.002

35. Medici M, Edward Visser W, Visser TJ, Peeters RP. Genetic determination of the hypothalamic-pituitary-thyroid axis: where do we stand? Endocr Rev. (2015) 36:215-44. doi: 10.1210/er.2014-1081

36. Murphy E, Glüer CC, Reid DM, Felsenberg D, Roux C, Eastell R, et al. Thyroid function within the upper normal range is associated with reduced bone mineral density and an increased risk of nonvertebral fractures in healthy euthyroid postmenopausal women. J Clin Endocrinol Metab. (2010) 95:3173-81. doi: 10.1210/jc.2009-2630

37. Cappola AR, Arnold AM, Wulczyn K, Carlson M, Robbins J, Psaty BM. Thyroid function in the euthyroid range and adverse outcomes in older adults. J Clin Endocrinol Metab. (2015) 100:1088-96. doi: 10.1210/jc.2014-3586

38. Ruhla S, Weickert MO, Arafat AM, Osterhoff M, Isken F, Spranger J, Schöfl C, et al. A high normal TSH is associated with the metabolic syndrome. Clin Endocrinol. (2010) 72:696-701. doi: 10.1111/j.1365-2265.2009.03698.x

39. Taylor P, Razvi S, Pearce S, Dayan C. Clinical review: a review of the clinical consequences of variation in thyroid function within the reference range. $J$ Clin Endocrinol Metab. (2013) 98:3562-71. doi: 10.1210/jc.2013-1315

40. Andersen S, Pedersen KM, Bruun NH, Laurberg P. Narrow individual variations in serum $\mathrm{T}(4)$ and $\mathrm{T}(3)$ in normal subjects: a clue to the understanding of subclinical thyroid disease. J Clin Endocrinol Metab. (2002) 87:1068-72. doi: 10.1210/jcem.87.3.8165

41. Pedersen IB, Knudsen N, Jørgensen T, Perrild H, Ovesen L, Laurberg P. Large differences in incidences of overt hyper- and hypothyroidism associated with a small difference in iodine intake: a prospective comparative register-based population survey. J Clin Endocrinol Metab. (2002) 87:4462-9. doi: $10.1210 /$ jc.2002-020750

42. Andersen SL, Olsen J, Wu C Sen, Laurberg P. Smoking reduces the risk of hypothyroidism and increases the risk of hyperthyroidism: evidence from 450,842 mothers giving birth in Denmark. Clin Endocrinol. (2014) 80:307-14. doi: 10.1111/cen.12279

43. Persani L, Calebiro D, Cordella D, Weber G, Gelmini G, Libri D, et al. Genetics and phenomics of hypothyroidism due to TSH resistance. Mol Cell Endocrinol. (2010) 322:72-82. doi: 10.1016/j.mce.2010.01.008

44. Grasberger H, Refetoff S. Genetic causes of congenital hypothyroidism due to dyshormonogenesis. Curr Opin Pediatr. (2011) 23:421-8. doi: 10.1097/MOP.0b013e32834726a4

45. Gumieniak O, Perlstein TS, Williams JS, Hopkins PN, Brown NJ, Raby BA, et al. Ala92 type 2 deiodinase allele increases risk for the development of hypertension. Hypertension. (2007) 49:461-6. doi: 10.1161/01.HYP.0000256295.72185.fd

46. Guerra A, Sapio MR, Carrano M, Di Stasi V, Volpe A, Murino A, et al. Prevalence of Dio2(T92A) polymorphism and its association with thyroid autoimmunity. J Endocrinol Invest. (2013) 36:303-6. doi: 10.3275/8618

47. de Jong FJ, Peeters RP, den Heijer T, van der Deure WM, Hofman A, Uitterlinden AG, et al. The association of polymorphisms in the type 1 and 2 deiodinase genes with circulating thyroid hormone parameters and atrophy of the medial temporal lobe. J Clin Endocrinol Metab. (2007) 92:636-40. doi: 10.1210/jc.2006-1331

48. Canani LH, Leie MA, Machado WE, Capp C, Maia AL. Type 2 deiodinase Thr92Ala polymorphism is not associated with arterial hypertension in type 2 diabetes mellitus patients. Hypertension. (2007) 49:47. doi: 10.1161/HYPERTENSIONAHA.107.088278

49. van der Deure WM, Peeters RP, Uitterlinden AG, Hofman A, Breteler MM, Witteman J, et al. Impact of thyroid function and polymorphisms in the type 2 deiodinase on blood pressure: the Rotterdam Study and the Rotterdam Scan Study. Clin Endocrinol. (2009) 71:137-44. doi: 10.1111/j.1365-2265.2008.03447.x

50. Garcia S, Porto P, Dieuzeide G, Landa M, Kirszner T, Plotquin $\mathrm{Y}$, et al. Thyrotropin-releasing hormone receptor (TRHR) gene is 
associated with essential hypertension. Hypertension. (2001) 38:683-7. doi: 10.1161/01.HYP.38.3.683

51. Collet T-H, Gussekloo J, Bauer DC, den Elzen WPJ, Cappola AR, Balmer P, et al. Subclinical hyperthyroidism and the risk of coronary heart disease and mortality. Arch Intern Med. (2013) 172:799-809. doi: 10.1001/archinternmed.2012.402.Subclinical

52. Muthukumar S, Sadacharan D, Ravikumar K, Mohanapriya G, Hussain Z, Suresh R. A prospective study on cardiovascular dysfunction in patients with hyperthyroidism and its reversal after surgical cure. World J Surg. (2016) 40:622-8. doi: 10.1007/s00268-015-3352-6

53. Sugiura T, Yamanaka S, Takeuchi H, Morimoto N, Kamioka M, Matsumura Y. Autoimmunity and pulmonary hypertension in patients with Graves' disease. Heart Vessels. (2015) 30:642-6. doi: 10.1007/s00380-014-0518-3

54. Armigliato M, Paolini R, Aggio S, Zamboni S, Galasso MP, Zonzin $\mathrm{P}$, et al. Hyperthyroidism as a cause of pulmonary arterial hypertension: a prospective study. Angiology. (2006) 57:600-6. doi: $10.1177 / 0003319706293131$

55. Mazza A, Beltramello G, Armigliato M, Montemurro D, Zorzan S, Zuin $\mathrm{M}$, et al. Arterial hypertension and thyroid disorders: What is important to know in clinical practice? Ann Endocrinol. (2011) 72:296-303. doi: 10.1016/j.ando.2011.05.004

56. Iglesias P, Acosta M, Sánchez R, Fernández-Reyes MJ, Mon C, Díez JJ. Ambulatory blood pressure monitoring in patients with hyperthyroidism before and after control of thyroid function. Clin Endocrinol. (2005) 63:6672. doi: $10.1111 /$ j.1365-2265.2005.02301.x

57. Lillevang-Johansen M, Abrahamsen B, Jørgensen HL, Brix TH, Hegedüs L. Duration of hyperthyroidism and lack of sufficient treatment are associated with increased cardiovascular risk. Thyroid. (2019) 10:1-9. doi: 10.1089/thy.2018.0320

58. Delitala AP. Subclinical Hyperthyroidism and the Cardiovascular Disease. Horm Metab Res. (2017) 49:723-31. doi: 10.1055/s-0043-117893

59. Manolis AA, Manolis TA, Melita H, Manolis AS. Subclinical thyroid dysfunction and cardiovascular consequences: an alarming wake-up call? Trends Cardiovasc Med. (2019) 1:1-13. doi: 10.1016/j.tcm.2019.02.011

60. Biondi B, Palmieri EA, Fazio S, Cosco C, Nocera M, Saccà L, et al. Endogenous subclinical hyperthyroidism affects quality of life and cardiac morphology and function in young and middle-aged patients. $J$ Clin Endocrinol Metab. (2000) 85:4701-5. doi: 10.1210/jc.85.12.4701

61. Sawin CT, Geller A, Wolf PA, Belanger AJ, Baker E, Bacharach P, et al. Low serum thyrotropin concentrations as a risk factor for atrial fibrillation in older persons. N Engl J Med. (1994) 331:1249-52. doi: 10.1056/nejm199411103311901

62. Popławska-Kita A, Siewko K, Telejko B, Modzelewska A, Myśliwiec J, Milewski R, et al. The changes in the endothelial function and haemostatic and inflammatory parameters in subclinical and overt hyperthyroidism. Int J Endocrinol. (2013) 2013:981638. doi: 10.1155/2013/981638

63. Riis ALD, Gravholt CH, Djurhuus CB, Nørrelund H, Jørgensen JOL, Weeke J, et al. Elevated regional lipolysis in hyperthyroidism. J Clin Endocrinol Metab. (2002) 87:4747-53. doi: 10.1210/jc.2002-020174

64. Bano A, Chaker L, Mattace-Raso FUS, Van Der Lugt A, Ikram MA, Franco $\mathrm{OH}$, et al. Thyroid function and the risk of atherosclerotic cardiovascular morbidity and mortality: the rotterdam study. Circ Res. (2017) 121:1392-400. doi: 10.1161/CIRCRESAHA.117.311603

65. Gencer B, Collet TH, Virgini V, Bauer DC, Gussekloo J, Cappola AR, et al. Subclinical thyroid dysfunction and the risk of heart failure events an individual participant data analysis from 6 prospective cohorts. Circulation. (2012) 126:1040-9. doi: 10.1161/CIRCULATIONAHA.112.096024

66. Völzke H, Ittermann T, Schmidt CO, Dörr M, John U, Wallaschofski H, et al. Subclinical hyperthyroidism and blood pressure in a populationbased prospective cohort study. Eur J Endocrinol. (2009) 161:615-21. doi: 10.1530/EJE-09-0376

67. Cai Y, Ren Y, Shi J. Blood pressure levels in patients with subclinical thyroid dysfunction: a meta-analysis of cross-sectional data. Hypertens Res. (2011) 34:1098-1105. doi: 10.1038/hr.2011.91

68. Duntas LH, Brenta G. The effect of thyroid disorders on lipid levels and metabolism. Med Clin North Am. (2012) 96:269-81. doi: 10.1016/j.mcna.2012.01.012
69. Nikkilä EA, Kekki M. Plasma triglyceride metabolism in thyroid disease. J Clin Invest. (1972) 51:2103-14. doi: 10.1172/JCI107017

70. Lithell H, Boberg J, Hellsing K, Ljunghall S, Lundqvist G, Vessby $B$, et al. Serum lipoprotein and apolipoprotein concentrations and tissue lipoprotein-lipase activity in overt and subclinical hypothyroidism: the effect of substitution therapy. Eur J Clin Invest. (1981) 11:3-10. doi: 10.1111/j.1365-2362.1981.tb01758.x

71. Duntas LH, Brenta G. Thyroid hormones: a potential ally to LDL-cholesterol-lowering agents. Hormones. (2016) 15:500-10. doi: 10.14310/horm.2002.1707

72. Thompson GR, Soutar AK, Spengel FA, Jadhav A, Gavigan SJ, Myant NB. Defects of receptor-mediated low density lipoprotein catabolism in homozygous familial hypercholesterolemia and hypothyroidism in vivo. Proc Nat Acad Sci USA. (1981) 78:2591-5. doi: 10.1073/pnas.78.4.2591

73. Pykälistö O, Goldberg AP, Brunzell JD. Reversal of decreased human adipose tissue lipoprotein lipase and hypertriglyceridemia after treatment of hypothyroidism. J Clin Endocrinol Metab. (1976) 43:591-600. doi: 10.1210/jcem-43-3-591

74. Åsvold BO, Vatten LJ, Nilsen TIL, Bjøro T. The association between TSH within the reference range and serum lipid concentrations in a populationbased study. The HUNT Study. Eur J Endocrinol. (2007) 156:181-6. doi: $10.1530 /$ eje.1.02333

75. Steinberg D, Parthasarathy S, Carew TE, Khoo JC, Witztum JL. Beyond Cholesterol. N Engl J Med. (1989) 320:915-24. doi: 10.1056/NEJM198904063201407

76. Rizos CV. Effects of thyroid dysfunction on lipid profile. Open Cardiovasc Med J. (2011) 5:76-84. doi: 10.2174/1874192401105010076

77. Asvold BO, Bjøro T, Vatten LJ. Associations of TSH levels within the reference range with future blood pressure and lipid concentrations: 11year follow-up of the HUNT study. Eur J Endocrinol. (2013) 169:73-82. doi: 10.1530/EJE-13-0087

78. O'Brien T, Dinneen SF, O'Brien PC, Palumbo PJ. Hyperlipidemia in patients with primary and secondary hypothyroidism. Mayo Clin Proc. (1993) 68:860-6. doi: 10.1016/S0025-6196(12)60694-6

79. Hak AE, Pols HAP, Visser TJ, Drexhage HA, Hofman A, Witteman JCM. Subclinical hypothyroidism is an independent risk factor for atherosclerosis and myocardial infarction in elderly women: the Rotterdam Study. Ann Intern Med. (2000) 132:270-8. doi: 10.7326/0003-4819-132-4-200002150-00030

80. Obuobie K, Smith J, Evans LM, John R, Davies JS, Lazarus JH. Increased central arterial stiffness in hypothyroidism. J Clin Endocrinol Metab. (2002) 87:4662-6. doi: 10.1210/jc.2002-020493

81. Müller B, Tsakiris DA, Roth CB, Guglielmetti M, Staub JJ, Marbet GA. Haemostatic profile in hypothyroidism as potential risk factor for vascular or thrombotic disease. Eur J Clin Invest. (2001) 31:131-7. doi: 10.1046/j.1365-2362.2001.00777.x

82. Erbil Y, Ozbey N, Giriş M, Salmaslioglu A, Ozarmagan S, Tezelman S. Effects of thyroxine replacement on lipid profile and endothelial function after thyroidectomy. Br J Surg. (2007) 94:1485-90. doi: 10.1002/bjs.5915

83. Roos A, Bakker SJL, Links TP, Gans ROB, Wolffenbuttel BHR. Thyroid function is associated with components of the metabolic syndrome in euthyroid subjects. J Clin Endocrinol Metab. (2007) 92:491-6. doi: 10.1210/jc.2006-1718

84. Iqbal A, Jorde R, Figenschau Y. Serum lipid levels in relation to serum thyroid-stimulating hormone and the effect of thyroxine treatment on serum lipid levels in subjects with subclinical hypothyroidism: the Tromsø Study. J Intern Med. (2006) 260:53-61. doi: 10.1111/j.1365-2796.2006. 01652.x

85. Razvi S, Ingoe L, Keeka G, Oates C, McMillan C, Weaver JU. The beneficial effect of L-thyroxine on cardiovascular risk factors, endothelial function, and quality of life in subclinical hypothyroidism: Randomized, crossover trial. J Clin Endocrinol Metab. (2007) 92:1715-23. doi: 10.1210/jc.20 06-1869

86. Teixeira PFS, Reuters VS, Ferreira MM, Almeida CP, Reis FAA, Melo BA, et al. Treatment of subclinical hypothyroidism reduces atherogenic lipid levels in a placebo-controlled double-blind clinical trial. Horm Metab Res. (2008) 40:50-5. doi: 10.1055/s-2007-993216 
87. Ordookhani A, Burman KD. Hemostasis in hypothyroidism and autoimmune thyroid disorders. Int J Endocrinol Metab. (2017) 15:426-49. doi: 10.5812/ijem.42649

88. Erem C. Thyroid disorders and hypercoagulability. Semin Thromb Hemost. (2011) 37:17-26. doi: 10.1055/s-0030-1270067

89. Cai Y, Manio MM, Leung GPH, Xu A, Tang EHC, Vanhoutte PM. Thyroid hormone affects both endothelial and vascular smooth muscle cells in rat arteries. Eur J Pharmacol. (2015) 747:18-28. doi: 10.1016/j.ejphar.2014.11.036

90. Liu J, Guo T, Zhang L, Gao C, Ni J, Tian L. Effects of TSH on the function of human umbilical vein endothelial cells. J Mol Endocrinol. (2014) 52:215-22. doi: 10.1530/jme-13-0119

91. Borges JP, Lopes GO, Verri V, Coelho MP, Nascimento P, Kopiler DA, et al. A novel effective method for the assessment of microvascular function in male patients with coronary artery disease: a pilot study using laser speckle contrast imaging. Brazil J Med Biol Res. (2016) 49:e5541. doi: 10.1590/1414-431X20165541

92. Bellamkonda K, Williams M, Handa A, Lee R. Flow mediated dilatation as a biomarker in vascular surgery research. J Atheroscler Thromb. (2017) 24:779-87. doi: 10.5551/jat.40964

93. Lekakis J, Papamichael C, Alevizaki M, Piperingos G, Mantzos J, Marafelia P, et al. Flow-mediated, endothelium-dependent vasodilatation is impaired in subjects with hypothyroidism, borderline hypothyroidism, and high-normal serum thyrotropin (TSH) values. Thyroid. (1997) 7:411-4. doi: 10.1089/thy.1997.7.411

94. Cikim AS, Ozbey N, Meric M, Cikim K, Umman S, Sencer E, et al. Evaluation of endothelial function in subclinical hypothyroidism and subclinical hyperthyroidism. Thyroid. (2004) 14:605-9. doi: 10.1089/1050725041692891

95. Rodondi N, Newman AB, Vittinghoff E, De Rekeneire N, Satterfield S, Harris TB, et al. Subclinical hypothyroidism and the risk of heart failure, other cardiovascular events, and death. Arch Intern Med. (2005) 165:2460-6. doi: 10.1001/archinte.165.21.2460

96. Murray CSG, Nahar T, Kalashyan H, Becher H, Nanda NC. Ultrasound assessment of carotid arteries: current concepts, methodologies, diagnostic criteria, and technological advancements. Echocardiography. (2018) 35:207991. doi: 10.1111/echo.14197

97. Assem M, Saif A, Abdelhamid A, Tharwat N, Mousa S. Endothelial dysfunction and the risk of atherosclerosis in overt and subclinical hypothyroidism. Endocr Connect. (2018) 7:1075-80. doi: 10.1530/ec-18-0194

98. Arnett DK, Evans GW, Riley WA. Arterial stiffness: a new cardiovascular risk factor? Am J Epidemiol. (1994) 140:669-82. doi: 10.1093/oxfordjournals.aje.a117315

99. Owen PJ, Rajiv C, Vinereanu D, Mathew T, Fraser A, Lazarus J. Subclinical hypothyroidism, arterial stiffness, and myocardial reserve. J Clin Endocrinol Metab. (2006) 91:2126-32. doi: 10.1210/jc.2005-2108

100. Saito I, Ito K, Saruta T. Hypothyroidism as a cause of hypertension. Hypertension. (1983) 5:112-5. doi: 10.1161/01.HYP.5.1.112

101. Purohit P, Mathur R. Hypertension association with serum lipoproteins, insulin, insulin resistance and C-peptide: unexplored forte of cardiovascular risk in hypothyroidism. N Am J Med Sci. (2013) 5:195-201. doi: 10.4103/1947-2714.109187

102. Williams B, Mancia G, Spiering W, Rosei EA, Azizi M, Burnier M, et al. 2018 ESC/ESH Guidelines for the management of arterial hypertension. Eur Heart J. (2018) 39:3021-3104. doi: 10.1093/eurheartj/ehy339

103. Parati G, Stergiou G, O’Brien E, Asmar R, Beilin L, Bilo G, Clement $\mathrm{D}$, et al. European society of hypertension practice guidelines for ambulatory blood pressure monitoring. J Hypertens. (2014) 32:1359-66. doi: 10.1097/HJH.0000000000000221

104. Kang YY, Li Y, Huang QF, Song J, Shan XL, Dou Y, et al. Accuracy of home versus ambulatory blood pressure monitoring in the diagnosis of white-coat and masked hypertension. J Hypertens. (2015) 33:1580-7. doi: 10.1097/HJH.0000000000000596

105. Piantanida E, Gallo D, Veronesi G, Pariani N, Masiello E, Premoli P, et al. Masked hypertension in newly diagnosed hypothyroidism: a pilot study. $J$ Endocrinol Invest. (2016) 39:1131-8. doi: 10.1007/s40618-016-0488-7

106. Ittermann T, Tiller D, Meisinger C, Agger C, Nauck M, Rettig R, et al. High serum thyrotropin levels are associated with current but not with incident hypertension. Thyroid. (2013) 23:955-63. doi: 10.1089/thy.2012.0626
107. Botella-Carretero JI, Gómez-Bueno M, Barrios V, Caballero C, GarcíaRobles R, Sancho J, et al. Chronic thyrotropin-suppressive therapy with levothyroxine and short-term overt hypothyroidism after thyroxine withdrawal are associated with undesirable cardiovascular effects in patients with differentiated thyroid carcinoma. Endocr Relat Cancer. (2004) 11:34556. doi: $10.1677 /$ erc. 0.0110345

108. Mayer O, Šimon J, Filipovský J, Pláškova M, Pikner R. Hypothyroidism in coronary heart disease and its relation to selected risk factors. Vasc Health Risk Manag. (2006) 2:499-506. doi: 10.2147/vhrm.2006.2. 4.499

109. Åsvold BO, Bjøro T, Nilsen T IL, Vatten LJ. Association between blood pressure and serum thyroid-stimulating hormone concentration within the reference range: a population-based study. J Clin Endocrinol Metab. (2007) 92:841-5. doi: 10.1210/jc.2006-2208

110. Liu D, Jiang F, Shan Z, Wang B, Wang J, Lai Y, et al. A cross-sectional survey of relationship between serum TSH level and blood pressure. J Hum Hypertens. (2010) 24:134-8. doi: 10.1038/jhh.2009.44

111. Duan Y, Peng W, Wang X, Tang W, Liu X, Xu S, et al. Communitybased study of the association of subclinical thyroid dysfunction with blood pressure. Endocrine. (2009) 35:136-42. doi: 10.1007/s12020-008-9138-y

112. Coban E, Aydemir M, Yazicioglu G, Ozdogan M. Endothelial dysfunction in subjects with subclinical hyperthyroidism. J Endocrinol Invest. (2006) 29:197-200. doi: 10.1007/BF03345539

113. Völzke H, Robinson DM, Schminke U, Lüdemann J, Rettig R, Felix SB, et al. Thyroid function and carotid wall thickness. J Clin Endocrinol Metab. (2004) 89:2145-9. doi: 10.1210/jc.2003-031028

114. Cappola AR, Fried LP, Arnold AM, Danese MD, Kuller LH, Burke GL, et al. Thyroid status, cardiovascular risk, and mortality in older adults. JAMA. (2006) 295:1033-41. doi: 10.1001/jama.295.9.1033

115. Dörr M, Wolff B, Robinson DM, John U, Lüdemann J, Meng W, et al. The association of thyroid function with cardiac mass and left ventricular hypertrophy. J Clin Endocrinol Metab. (2005) 90:673-7. doi: $10.1210 /$ jc. $2004-1554$

116. Ittermann T, Thamm M, Wallaschofski H, Rettig R, Völzke H. Serum thyroid-stimulating hormone levels are associated with blood pressure in children and adolescents. J Clin Endocrinol Metab. (2012) 97:828-34. doi: 10.1210/jc.2011-2768

117. Laurberg P, Pedersen KM, Hreidarsson A, Sigfusson N, Iversen E, Knudsen PR. Iodine intake and the pattern of thyroid disorders: a comparative epidemiological study of thyroid abnormalities in the elderly in Iceland and in Jutland, Denmark. J Clin Endocrinol Metab. (1998) 83:765-9. doi: $10.1210 /$ jcem.83.3.4624

118. Takashima N, Niwa Y, Mannami T, Tomoike H, Iwai N. Characterization of subclinical thyroid dysfunction from cardiovascular and metabolic viewpoints: the Suita study. Circ J. (2007) 71:191-5. doi: 10.1253/circj.71.191

119. Delange F, de Benoist B, Burgi H, Azizi F, Hajipour J, Benmiloud M, et al. Determining median urinary iodine concentration that indicates adequate iodine intake at population level. Bull World Health Organ. (2002) 80:633-6. doi: 10.1590/s0042-96862002000800007

120. Stehle G, Hinohara S, Cremer P, Feng Z, Bernhardt R, Dempfle CE, et al. Risk factor patterns for coronary heart disease in China, Japan and Germany. Chin Med J (Engl). (1992) 105:356-9. doi: 10.1016/j.chemphyslip.2015.07.019

121. He W, Li S, Zhang JA, Zhang J, Mu K, Li XM. Effect of levothyroxine on blood pressure in patients with subclinical hypothyroidism: a systematic review and meta-analysis. Front Endocrinol. (2018) 9:454. doi: 10.3389 /fendo. 2018.00454

Conflict of Interest Statement: The authors declare that the research was conducted in the absence of any commercial or financial relationships that could be construed as a potential conflict of interest.

Copyright (c) 2019 Berta, Lengyel, Halmi, Zrínyi, Erdei, Harangi, Páll, Nagy and Bodor. This is an open-access article distributed under the terms of the Creative Commons Attribution License (CC BY). The use, distribution or reproduction in other forums is permitted, provided the original author(s) and the copyright owner(s) are credited and that the original publication in this journal is cited, in accordance with accepted academic practice. No use, distribution or reproduction is permitted which does not comply with these terms. 